\title{
THEORETICAL ASPECTS OF MODERN QUALITATIVE METHODS FOR CRISIS MANAGEMENT
}

\author{
Alona Klodane' ${ }^{1}$ Anda Zvaigzne ${ }^{2}$, Karlis Poznakovs ${ }^{3}$, \\ Andris Pelss ${ }^{4}$ \\ ${ }^{1}$ Mg.soc.sc., lecturer, Rezekne Academy of Technologies, Rezekne, Latvia, \\ e-mail: alona.klodane@rta.lv \\ ${ }^{2}$ Dr.oec., associate professor, leading researcher Rezekne Academy of Technologies, \\ Rezekne, Latvia, e-mail: anda.zvaigzne@rta.lv \\ ${ }^{3}$ Mg.soc.sc., research assistant, Rezekne Academy of Technologies, Rezekne, Latvia, \\ e-mail: karlis.poznakovs@gmail.com \\ ${ }^{4}$ Mg.oec., lecturer, Rezekne Academy of Technologies, Rezekne, Latvia, \\ e-mail: andrispelss@inbox.lv
}

\begin{abstract}
Scientists agree on necessity to predict and timely detect a company crisis that is an integral part of business nowadays. The early identification of a company financial failure due to rapidly changing social, economic and environmental conditions is a topic of growing importance. The sooner a potential financial failure can be identified, the more effective and efficient the anti-crisis measures could be implemented. If a company financial failure could be predicted accurately, it might be possible for the business to be restructured, thus avoiding the failure. This would benefit the owners, shareholders, employees, creditors, and others interested alike.

The modern economic literature provides varied crisis diagnosis methods, mostly based on an analysis of key financial ratios. Less attention is paid to qualitative methods. Therefore, the present research aims to examine modern qualitative methods for company crisis diagnosis (prediction) in crisis management theory.

The research used the theoretical findings of foreign scientists and Internet resources. The research employed the following methods: analysis and synthesis, induction and deduction, the monographic method, document analysis and the graphic method.

The paper provides definitions of main terms related to company failure prediction and a description of general qualitative models of company financial failure (bankruptcy) prediction.
\end{abstract}

Keywords: business failure, qualitative prediction methods, the A score model. JEL code: $M 10$.

\section{Introduction}

Modern researchers (Piesse et al., 2013; Situm, 2013; Кучр, 2016; Крюков, Егорычев, 2001; Garcia-Gallego, Mures-Quintana, 2012) agree on necessity to predict and timely detect a company crisis that is an integral part of business nowadays. The early identification of a company financial failure due to rapidly changing social, economic and environmental conditions is a topic of growing importance. The sooner a potential financial failure could be identified, the more effective and efficient the anti-crisis measures could be implemented. If a company financial failure could be predicted accurately, it 
might be possible for the business to be restructured, thus avoiding the failure. This would benefit the owners, shareholders, employees, creditors, and others interested alike.

The modern economic literature provides varied crisis diagnosis methods, mostly based on an analysis of key financial ratios.

The first studies of analytical ratios aimed to predict possible failures in companies' financial activities were conducted in the United States in the early thirties of the XX century (Крюков, Егорычев, 2001). One of the first significant research papers in the field related to business failure prediction was published by Beaver (Beaver, 1966), an American professor and researcher of accounting, who introduced a dichotomous classification test for the separation of failed and non-failed firms based on some chosen financial ratios (Situm, 2013). The next well-known research of bankruptcy prediction was published by Altman in 1968 (Altman, 1968), where he represents his multiple linear discriminant analysis. Quantitative information analysis is employed by foreign authors in their models, and most Latvian researchers also use quantitative indicators for analysing company financial positions, e.g. M.Januška (Januška, 2002), R.Šneidere, (Šneidere, 2009), I.Genriha and I.Voronova (Genriha, Voronova, 2010). Less attention is paid to qualitative methods.

Therefore, present research aims to examine modern qualitative methods for company crisis diagnosis (prediction) in crisis management theory.

To achieve the research aim, the following specific research tasks have been set:

1. to analyse and define the main terms related to company failure prediction;

2. to provide a description of general qualitative models of company financial failure (bankruptcy) prediction.

The research used the theoretical findings of foreign scientists and internet resources.

The research employed the following methods: analysis and synthesis, induction and deduction, the monographic method, document analysis and the graphic method.

\section{Research results and discussion}

For decades, predicting company crises has been an interesting subject of financial research for both researchers and practitioners (Bunyainu, Bashiru, 2014), thereby creating a number of models and methods for company crisis prediction. 
The purpose of a diagnosis is to draw a conclusion (make a diagnosis) on the condition of the entity on the date the diagnosis was completed and in the future (Некрасова, 2016). According to the findings of modern researchers (Некрасова, 2016; Асаул, Князь, Коротаева, 2007), it is important to divide a diagnosis of a potential crisis in two stages:

1) qualitative identification of the entity - the determination of its belonging to a particular category or group of entities;

2) quantitative identification of the entity - the determination of differences between the entity and the other entities of the same category by comparing the real parameters of the entity with those pertaining to the category.

Usually, any method for company bankruptcy prediction and crisis diagnosis (Altman, 1983; Zavgern, 1989; Beaver, 1966; Bunyainu, Bashiru, 2014) encompasses a binary classification of the entities examined that are divided in two categories: stable (no crisis indications) and unstable (with crisis indications).

Modern theoretical and applied research studies of company financial condition and crisis diagnosis have resulted in a consequent classification of relevant models into two basic categories: quantitative models and qualitative models. Qualitative models are most commonly defined as mathematical models for a company's crisis and bankruptcy prediction based on numerical, financial indicators (Асаул, Князь, Коротаева, 2007) and published financial information (Pogue, 2008). Qualitative methods, however, are based on expert assessments (Абалакина, 2016) and employ nonfinancial criteria.

Modern researcher T.Abalakina (Абалакина, 2016) points out that despite the fact that qualitative methods are more universal for any field of research and could be used if limited initial information is available as well as are biased; the methods could not be used to perform multi-criteria tasks. Besides, expert assessments are often more accurate when based on previous analyses of financial performance indicators. Quantitative methods are less universal and the methods and models developed abroad are difficult to adopt to diagnose a crisis and predict bankruptcy for a domestic company. In addition, the usefulness of ratio-based business failure prediction models in providing accurate predictions has been questioned. A research study (Bunyainu, Bashiru, 2014) gives examples where ratio-based models have been considered to be unreliable bankruptcy predictors: for example, a research study expected 132 companies would go bankrupt, whereas actually only five companies failed in five years. Another research study found that qualitative data could give as good predictions as traditional financial ratios. Accordingly, it is proposed that a combination of quantitative 
and qualitative models would provide a higher degree of accuracy in predicting a crisis and bankruptcy for a company.

Based on other relevant research studies (Абалакина, 2016; Асаул, Князь, Коротаева, 2007; Pogue, 2008; Дягель, Энгельгардт, 2008), the classification of company financial situations and methods for company crisis diagnosis could have three categories, supplementing the abovementioned categories with a category for a combination of the methods.

Quantitative methods for crisis diagnosis and bankruptcy prediction are actively researched, whereas qualitative and combined methods are less representative in the relevant literature. Table 1 shows qualitative methods for crisis diagnosis and bankruptcy prediction represented in a random sample of research studies.

Table 1 Qualitative business failure prediction methods in modern research (compiled by the authors)

\begin{tabular}{|c|c|c|c|c|}
\hline Source / Methods & $\begin{array}{c}\text { Argenti's } \\
\text { A score } \\
\text { model }\end{array}$ & $\begin{array}{l}\text { Two-level system } \\
\text { of indicators for } \\
\text { forecasting } \\
\text { bankruptcy by } \\
\text { V.V. Kovalev }\end{array}$ & $\begin{array}{l}\text { System of } \\
\text { indicators for } \\
\text { forecasting } \\
\text { bankruptcy by } \\
\text { V.P. Privalov }\end{array}$ & $\begin{array}{c}\text { Cash flow } \\
\text { analysis } \\
\text { method }\end{array}$ \\
\hline Дорофеев, 2006 & $\mathrm{x}$ & $\mathrm{x}$ & & \\
\hline $\begin{array}{l}\text { Асаул, Князь, } \\
\text { Коротаева, } 2007\end{array}$ & $\mathrm{x}$ & $\mathrm{x}$ & & $\mathrm{x}$ \\
\hline $\begin{array}{l}\text { Дягель, } \\
\text { Энгельгардт, } 2008\end{array}$ & $\mathrm{x}$ & $\mathrm{x}$ & $\mathrm{x}$ & \\
\hline Pogue, 2008 & $\mathrm{x}$ & & & \\
\hline $\begin{array}{l}\text { Bunyainu, Bashiru, } \\
2014\end{array}$ & $\mathrm{x}$ & & & \\
\hline Ncube, 2014 & $\mathrm{x}$ & & & \\
\hline Туктарова, 2018 & $\mathrm{x}$ & & & \\
\hline
\end{tabular}

The most notable qualitative model is Argenti's A score model (Bunyainu, Bashiru, 2014), which is shown in Table 1. Argenti suggested that the failure process follows a predictable sequence: defects, mistakes, symptoms of failure (Figure 1 ).

If applying Argenti's A score model to a particular organisation, each "factor" of it has to be assigned a score, including zero for the factor that has not been identified, and then the total score has to be calculated. 


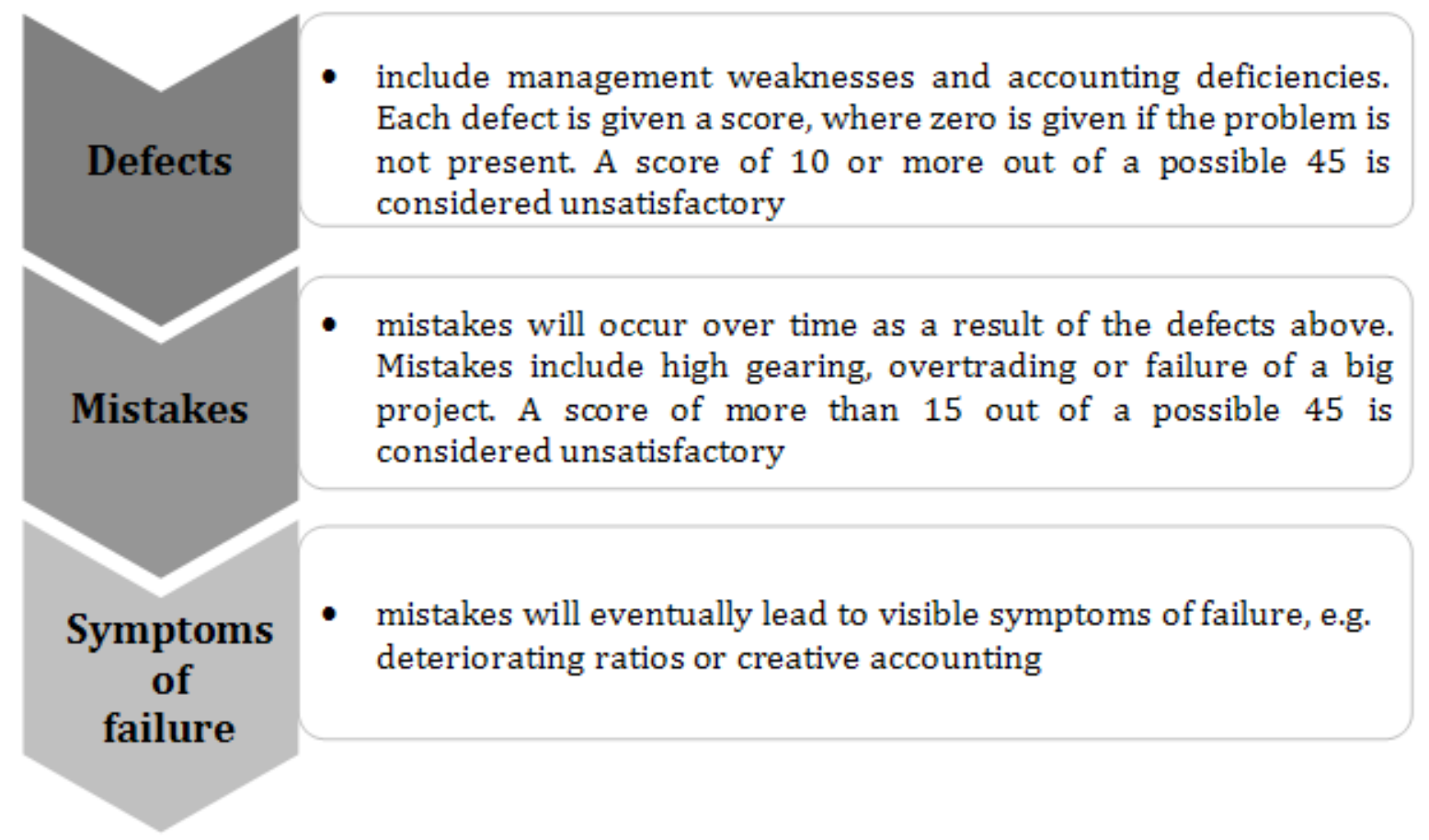

Fig.1 The qualitative A- score model of Argenti (compiled by the authors based on Bunyainu, Bashiru, 2014; Pogue, 2008; Туктарова, 2018)

Within the model, defects could be divided into two groups as follows (Pogue, 2008):

1. Management weaknesses:
a. autocratic chief executive (8 points);
b. failure to separate the roles of the chairman and the chief executive (4 points);
c. passive board of directors ( 2 points);
d. lack of balance of skills in the management team - financial, legal, marketing, etc. (4 points);
e. $\quad$ weak finance director ( 2 points);
f. lack of 'management in depth' (1 point);
g. poor response to change (15 points).

2. Accounting deficiencies:
a. no budgetary control (3 points);
b. no cash flow plans ( 3 points);
c. no costing system(3 points).

In his model, Argenti assumes that if a company's management is weak, it will inevitably make mistakes. The final stage of the process occurs when the symptoms of failure become visible (Ncube, 2014). Argenti classifies such symptoms of failure using the following categories:

1. Financial signs - in the A score context, these appear only towards the end of the failure process, in the last two years (4 points); 
2. Creative accounting - optimistic statements are made to the public and figures are altered (inventory valued higher, depreciation lower, etc.). Because of this, the outsider may not recognise any change, and failure, when it arrives, is therefore very rapid (4 points);

3. Non-financial signs - various signs include frozen management salaries, delayed capital expenditure, falling market share, rising staff turnover (3 points);

4. Terminal signs - at the end of the failure process, the financial and non-financial signs become so obvious that even the casual observer recognises them ( 1 point).

The overall pass score is 25 . However, if the total score makes it possible to assume that a company has no signs of crisis and could be regarded as stable in general, it is worth examining the score of each block individually. A high score for each block is likely to indicate potential problems in the given area that have to be addressed and tackled. An advantage of this model is its systematic and complex approach to predicting crisis phenomena, and a disadvantage is the bias of the prediction made.

The methods rarely referred to are the cash flow analysis method and V.V.Kovalev's model for forecasting bankruptcy. The cash flow analysis method deals with four groups of variables: revenues, expenditures, their balance and a balance on accrual basis (availability of funds in the current account). V.V.Kovalev's model represents a two-level system of variables, where: the first group includes criteria and variables whose unfavourable current values or changes indicate potential serious financial difficulties in the foreseeable future, including bankruptcy, while the second group includes criteria and variables whose unfavourable values do not indicate that the current financial situation could be considered critical. At the same time, they indicate that under certain circumstances or in the absence of effective measures, the situation could deteriorate sharply (Асаул, Князь, Коротаева, 2007).

Given the capability of solving a problem, which is characteristic of qualitative methods for diagnosis of probability of bankruptcy, under the conditions of limited initial information, novelty of the problem examined as well as universality of the methods regarding the scope of their application, which, of course, are the analytical strengths of the qualitative methods, a disadvantage of the expert assessment methods is that they have an increased probability of erroneous results. 


\section{Conclusions}

1. For decades, predicting company crises has been an interesting subject of financial research for both researchers and practitioners, thereby creating a number of models and methods for company crisis prediction.

2. Modern qualitative methods are more universal for any field of research and could be used if limited initial information is available as well as are biased; the methods could not be used to perform multi-criteria tasks. However, qualitative methods yield more accurate results because expert opinions are based on analyses of financial performance indicators.

3. In contrast, quantitative methods are less universal, and the methods and models developed abroad are difficult to adopt to diagnose a crisis and predict bankruptcy for a domestic company.

4. Crisis management is important for a company not only during a crisis; the results of a crisis assessment allows every company to timely assess the financial capacity and identify potential risks. Therefore, the authors recommend companies to apply qualitative methods for crisis diagnosis at regular intervals for the purpose of evaluating their business activities.

\section{References}

1. Altman, E.I. (1968). Financial Ratios, Discriminant Analysis and the Prediction of Corporate Bankruptcy. The Journal of Finance, Vol. 23, pp.589-609. Retrieved from https://www.jstor.org/stable/2978933?seq=1\#page_scan_tab_contents

2. Altman, E.I. (1983). Corporate Financial Distress: A Complete Guide to Predicting, Avoiding and Dealing with Bankruptcy. Toronto: Wiley \& Sons. 368 p.

3. Beaver, W.H. (1966). Financial Ratios as Predictors of Failure. Empirical Research in Accounting: Selected Studies, Vol. 4, pp.71-111. Retrieved from https://www.jstor.org/stable/2490171?seq=1\#page_scan_tab_contents

4. Bunyaminu, A., Bashiru, S. (2014). Corporate Failure Prediction: A Fresh Technique for Dealing Effectively With Normality Based On Quantitative and Qualitative Approach. International Journal of Financial Economics, Vol. 2. (1), pp.1-12. Retrieved from https://www.academia.edu/7255954/Corporate_Failure_ Prediction_A_Fresh_Technique_for_Dealing_Effectively_With_Normality_Based_On_ Quantitative_and_Qualitative_Approach

5. Garcia-Gallego, A., Mures-Quintana, M.J. (2012). Business failure Prediction Models: Finding the Connection between their Results and the Sampling Method. Economic computation and economic cybernetics studies and research. Academy of Economic Studies 3 (3), pp.157-168. Retrieved from https://www.researchgate.net/ publication/286361899_Business_failure_prediction_models_Finding_the_connecti on_between_their_results_and_the_sampling_method

6. Genriha, I., Voronova, I. (2010). Maksātnespējas noteikšanas model̦i Latvijas uzñēmumiem. RTU zinātniskie raksti. 3. sēr., Ekonomika un uzñēmējdarbība, pp. 38-50.

7. Januška, M. (2002). Firmas finansiāli ekonomiskā stāvokla analīzes metodika. Praktisks palīglìdzeklis. Rīga: ZKC SIA “Inovācija”, 40 p. 
8. Ncube, T. (2014). Predicting corporate failure. International Journal of Economics, Commerce and Management, Vol. II, Issue 11. Retrieved from http://ijecm.co.uk/wpcontent/uploads/2014/11/21130.pdf

9. Piesse, J., Lee, CF., Kuo, HC., Lin, L. (2013). Corporate Failure: Definitions, Methods, and Failure Prediction Models. Lee CF., Lee A. (eds) Encyclopedia of Finance, pp.479490.

10. Pogue, M. (2008). Business failure. Prediction and prevention. Retrieved from https://www.accaglobal.com/content/dam/acca/global/PDF-students/2012/ sa_jj08_mpogue.pdf

11. Situ, S. (2013). Business failure prediction models based on expert knowledge. Czech Journal of Social Sciences, Business and Economics, 2 (4), pp.28-45. Retrieved from https://www.academia.edu/13029000/Business_failure_prediction_models_based -on_expert_knowledge

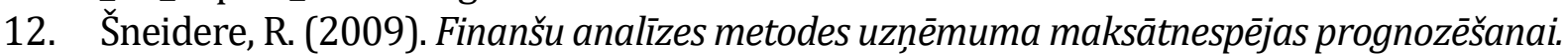
Rīga: Lietišķās informācijas dienests, 232 p.

13. Zavgren, C. (1989). How a Bankruptcy Model could be Incorporated as an Analytical Procedure. The CPA Journal, Retrieved from http://archives.cpajournal.com/ old/07505564.htm

14. Абалакина, Т.В. (2016). Методы диагностики финансового состояния в антикризисном управлении. Научный альманах, Экономические науки, N 8-1 (22), pp.24-28. Retrieved from http://ucom.ru/doc/na.2016.08.01.024.pdf

15. Асаул, А.Н., Князь, И.П., Коротаева, Ю.В. (2007). Теория и практика принятия решений по выходу организаций из кризиса. АНО «ИПЭВ», СПб, 224 р. Retrieved from http://www.aup.ru/books/m8/5_1.htm

16. Дорофеев, В.Д. и др. (2006). Антикризисное управление: учебное пособие. Изд-во Пензенского института экономического развития и антикризисного управления. Пенза. 209 р.

17. Дягель, О.Ю, Энгельгардт, Е.О., (2008). Диагностика вероятности банкротства организаций: сущность, задачи и сравнительная характеристика методов. Экономический анализ: теория и практика, 13 (118), 49-57. Retrieved from file:///C:/Users/PC/Desktop/diagnostika-veroyatnosti-bankrotstva-organizatsiysuschnost-zadachi-i-sravnitelnaya-harakteristika-metodov.pdf

18. Крюков, А.Ф., Егорычев, И.Г. (2002). Анализ методик прогнозирования кризисной ситуации коммерческих организаций с использованием финансовых индикаторов. Журнал Менеджмент в России и за рубежом, № 2, Retrieved from https://www.cfin.ru/press/management/2001-2/krukov. shtml\#1_1

19. Кучер, С.Э. (2016). Методики диагностики кризиса в организации. Экономика и социум, 12 (31), Retrieved from https://iupr.ru/domains_data/files/zurnal_ 31/Kucher\%20S.E.\%20-\%203\%20(Sovremennye\%20tehnologii\%20 upravleniya\%20organizaciyay).pdf

20. Некрасова, А.У. (2016). Антикризисное управление. Учебно-методическое пособие. КГУ им. Н.A. Некрасова, Кострома, 130 p. Retrieved from https://ksu.edu.ru/files/Svedeniya_ob_organisacii/OBRAZOVANYE/Obrazovateln ye\%20programmy/38.03.02/MO/Metod_Disc_38_03_02_19_09_16.pdf

21. Туктарова, Т.А. (2018). Диагностика банкротства промышленного предприятия в системе антикризисного менеджмента. Автореферат диссертации, ФГБОУ ВО «Санкт-Петербургский государственный экономический университет», Retrieved from https://search.rsl.ru/ru/record/01008700721 